\title{
Lamproitic Karashoho diamond deposit in Uzbekistan located within the Hercynian Tyan-Shan system
}

\author{
Alexandra V. Golovko ${ }^{1}$ and Felix V. Kaminsky ${ }^{2}$ \\ ${ }^{1}$ Central Geologic-Geophysical Expedition, State Committee on Geology and Mineral \\ Resources, Tashkent, Uzbekistan \\ ${ }^{2}$ KM Diamond Exploration Ltd., West Vancouver, BC, Canada
}

Since the 1980s, several diamondiferous ultramaficmafic rocks were found in Uzbekistan (Fig. 1). They were bulk-sampled and yielded thousands of diamond crystals. In the Karashoho area located in the periphery of the Kizil-Kum desert a sub-economic diamond grade was estimated.

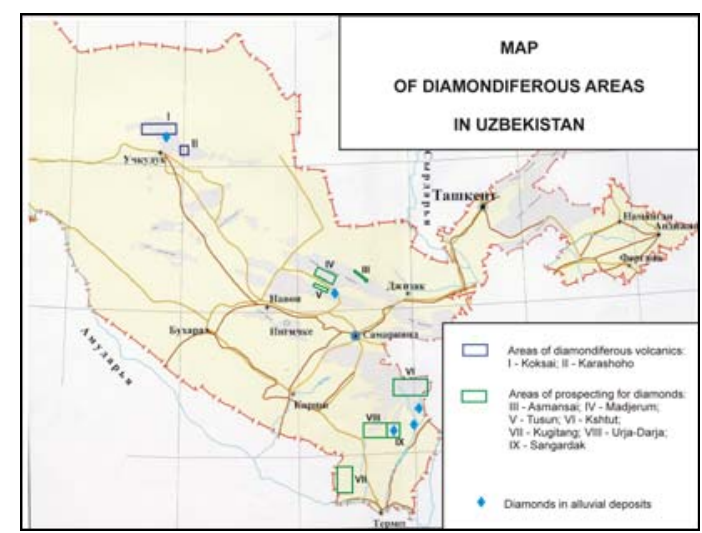

Fig. 1. Location of the Karashoho pipe and other diamondiferous areas in Uzbekistan

\section{Tectonic position}

The Karashoho area is located within the Sir-Daryin Massif which is a part of the Middle Tyan-Shan System. The latter is a Precambrian massif intensely reworked in the Caledonian and Hercynian epochs, simultaneously to the formation of the adjacent Caledonian Northern Tyan-Shan Folded System and the Hercynian Southern Tyan-Shan Folded System. The basement of the Middle Tyan-Shan System outcrops in the Kuylu-Sarydjaz area, in the southern part of the System, as the Kuylu Unit with an age at $2616 \pm 50 \mathrm{Ma}$ (U-Pb zircon age). The central and northern parts of the Middle Tyan-Shan System are overlain by a Mezo-Cenozoic cover of a young, Turan Plate, forming the Syr-Darya Medial Massif.

\section{Pipe Karashoho and its petrographic composition}

The pipe is an elongated (525 x $150 \mathrm{~m}$ ) lamproitic body which intrudes charts, mica shists, limestones, and dolomites of the Kokpaktas series, Upper Proterozoic age (Fig. 2). Lamproites are cut by Permian dioritic-lamprophyric dykes. The pipe contacts are sub-vertical with zones of brecciation up to a few meters thick. The pipe is drilled to the depth of $\sim 500 \mathrm{~m}$ and shows no significant changes in its size and shape at the depth. The Rb-Sr isochrone age of the lamprophyres is $353 \pm 13 \mathrm{Ma}$, i.e., Early-Carboniferous.

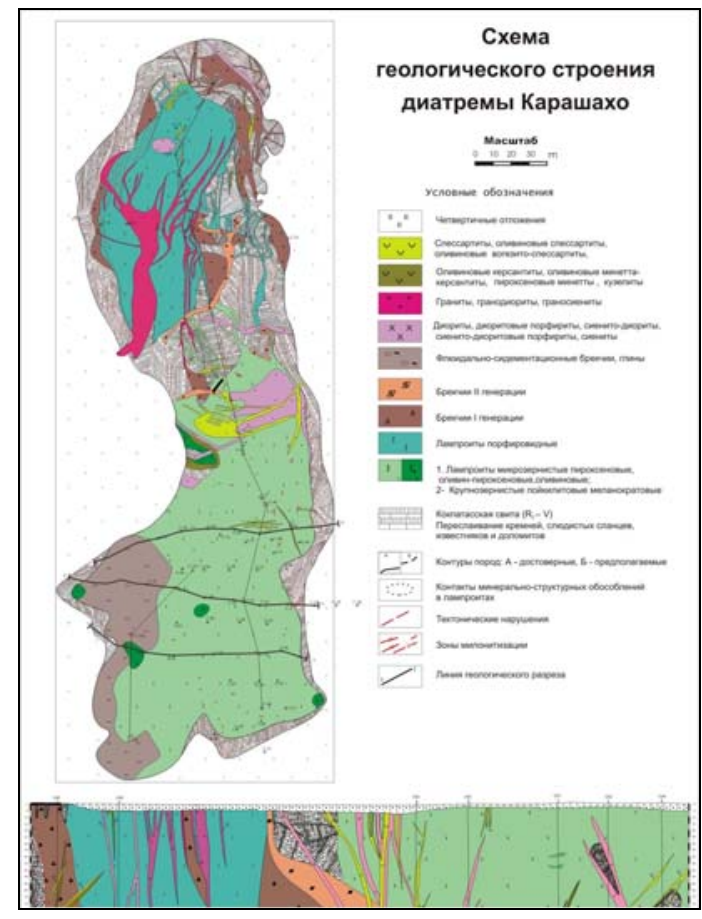

Fig. 2. Geological map of the Karashoho lamproitic pipe.

The pipe has a complex structure. It is composed of two adjacent stock-like bodies of massive lamproites surrounded by zones of volcanic breccias, also lamproitic in composition; each represents a separate phase of intrusion. The composition of the lamproites varies from melanocratic olivine- to pyroxenelamproites to leucocraic orenditic rocks rich in 
orthoclase and sanidine. Numerous xenoliths, in volcanic breccias, are represented by peridotites, pyroxenites, rodingites, and others including micaceous garnet peridotites and some exotic fragments as chrome-diopside + chromite + garnet + moissanite + diamond aggregate.

Olivine in lamproites is magnesian (80-93\% Fo), with an admixture of $\mathrm{Ca}(0.09-0.5 \% \mathrm{CaO}), \mathrm{Ni}$ (up to $0.4 \%$ $\mathrm{NiO})$ and $\mathrm{Cr}\left(0.02-0.35 \% \mathrm{Cr}_{2} \mathrm{O}_{3}\right)$. Phlogopite is highly magnesian $(m g=0.88-0.92)$ and contains up to 1.33 wt. $\% \mathrm{BaO}$.

Among accessory minerals in lamproites and lamproitic breccias, barite, apatite, zircon, rutile, disthen, andalusite, corundum, moissanite, ilmenite, staurolite, sillimanite, perovskite, garnet, chrome spinel and chrome-diopside were identified. Chrome spinel forms octahedra which may be deformed and rounded, 0.2-1 mm in size, with $\mathrm{Cr}_{2} \mathrm{O}_{3}$ from $53.4-63.4$ wt.\%. Among garnets, grossular-andradites and almandinepyropes were identified. Ilmenite is low-magnesian (usually $0.27-0.68$; rarely up to 4.5 wt.\% $\mathrm{MgO}$ ). Moissanite contains up to 1.06 wt. $\% \mathrm{Cr}_{2} \mathrm{O}_{3}$.

Chemically the Karashoho lamproites stay close to jumillites and orendites.

The Karashoho lamproites contain an epigenetic gold mineralization with a grade of $0.75-2.85 \mathrm{~g} /$ ton (in some zones up to $4.7 \mathrm{~g} /$ ton) which forms indicated resources as several tons of gold.

\section{Diamonds}

Among more than 200 studied diamonds from the Karashoho pipe, octahedra (including macles) strongly predominate (Fig. 3); most (69 \%) are colorless and transparent. Many of the diamonds bear mineral inclusions (silicates, chromite, rutile, graphite, and possibly sulphide).

Both the total nitrogen content (360-1900 ppm) and the nitrogen aggregation ratio in the Karashoho diamonds $(\% \mathrm{~B}=10-67 \%)$ vary widely. This possibly indicates the existence of several diamond populations in the lamproites.

The carbon isotopic composition of the Karashoho diamonds also varies widely from $-7.3 \%$ to $-13.8 \%$ o
PDB; this also points to the existence of different diamond associations: peridotitic and eclogitic.
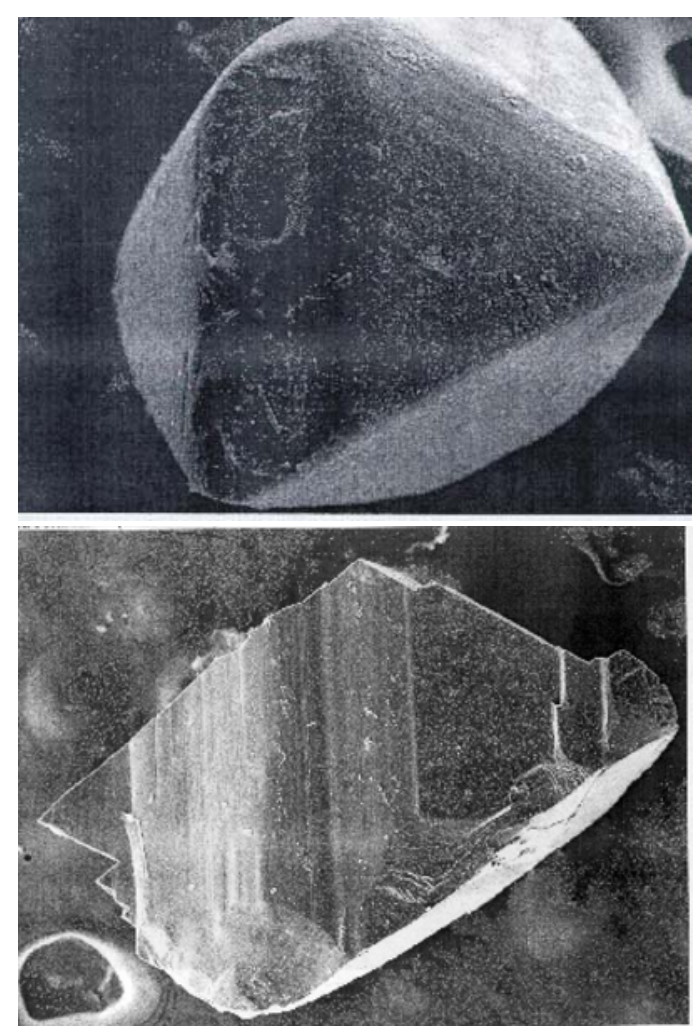

Fig. 3. Diamonds from the Karashoho pipe.

\section{Conclusions}

The Karashoho locality is an example of a nonkimberlitic, off-craton diamond deposit. It is located within the Hercynian Tyan-Shan Fold System which has an ancient, Archean basement and, possibly, a thick, mature lithospheric root. Early-Carboniferous lamproites contain diamonds which, judging by their properties, have a long thermal history. The diamonds are likely to be of different populations, and may have been formed at different stages of magmatic evolution.

The Karashoho-type diamond deposits may be found in other regions, and can explain the existence of placer diamond deposits in some off-cratonic areas, such as Kalimantan, Tasmania, New South Wales, and others. 